\title{
Prevalence of lip and perioral Ephelides in beach workers
}

\section{Prevalência de Éfelides labiais e periorais em trabalhadores de praias}

\author{
Eudes Euler de Souza Lucena ${ }^{1}$ \\ Danielle Bezerra de Farias ${ }^{2}$ \\ Éricka Janine Dantas da Silveira ${ }^{3}$
}

\author{
Ana Claúdia de Queiroz Castro² \\ Pérola Teixeira de Lima $^{2}$ \\ Kenio Costa de Lima ${ }^{4}$
}

\begin{abstract}
BACKGROUND: Ephelides are small hyperpigmented macules common in the skin, presenting as areas with increased melanin production. Ephelides are observed in genetically predisposed individuals, particularly fair-skinned people highly susceptible to sunburn.

OвJеCтIVEs: This study aimed to determine the prevalence of lip and perioral ephelides in 362 beach workers in the city of Natal (Rio Grande do Norte) and to investigate potential associations with sociodemographic, occupational and general health.

Methods: For this purpose clinical tests were performed by calibrated examiners in the epidemiological area around the lips and the area bounded laterally by the nasolabial groove and at the bottom by the chin. A questionnaire was completed and assessed. The possible associations between sociodemographic variables, occupational and general health with the presence of lip and perioral ephelides were evaluated by chi-square test for a significance level of 5\%.

Results: Approximately one third of the workers were affected by perioral ephelides (33.7\%) and around a quarter of them by lip ephelides (24.0\%). Gender was the only variable significantly associated with the presence of perioral ephelides $(\mathrm{p}=0.002)$, unlike lip ephelides which proved to be significantly associated with habits $(\mathrm{p}=0.036)$ and alcoholism (0.030).
\end{abstract}

Conclusions: The prevalence of ephelides in lip and perioral region was high in the study population, with gender and certain habits associated with its occurrence.

Keywords: Dermatomycoses; Cross-sectional studies; Skin diseases; Solar radiation

Resumo: FundAMENTOS: Efélides são máculas hiperpigmentadas pequenas, comuns na pele, que constituem uma área com maior aumento da produção de melanina. São observadas em indivíduos geneticamente predispostos, de pele clara, com grande suscetibilidade a queimaduras solares.

OвJETIvos: Esse estudo teve o propósito de verificar a prevalência de efélides labiais e periorais em 362 trabalhadores de praias do município de Natal/RN e investigar potenciais associações com variáveis sociodemográficas, ocupacionais e de saúde geral.

MÉTodos: Para tanto, foram realizados exames clínicos por examinadores calibrados, na área correspondente aos lábios e na área delimitada lateralmente pelo sulco nasolabial e inferiormente pelo mento, além de preenchimento de questionário validado. As possíveis associações das variáveis sociodemográficas, ocupacionais e de saúde geral com a presença de efélides labiais e periorais foram avaliadas pelo teste do qui-quadrado para um nível de significância de 5\%.

REsultados: Aproximadamente um terço dos trabalhadores foi acometido por efélides perioral (33,7\%) e um quarto por efélides labial (24,0\%). O gênero foi a única variável que se mostrou associada significativamente com a presença de efélides periorais $(\mathrm{p}=0,002)$, ao contrário das efélides labiais que mostrou-se associada significativamente com hábito $(\mathrm{p}=0,036)$ e etilismo $(0,030)$.

ConclusốEs: Conclui-se que a prevalência de efélides em região perioral e labial foi elevada na população estudada e o gênero e hábitos foram associadas à sua ocorrência.

Palavras-chave: Dermatopatias; Dermatomicoses; Estudos transversais; Radiação solar

\footnotetext{
Received on 01.03.2012

Approved by the Advisory Board and accepted for publication on 25.12.2012.

* Study undertaken at the Department of Odontology of the Federal University of Rio Grande do Norte (UFRN) - Natal (RN), Brazil. Conflict of interest: None

Financial funding: None

Master - Assistant Professor I, Federal University of Rio Grande do Norte (UFRN) - Natal (RN), Brazil.

Graduate student, Department of Odontology of the Federal University of Rio Grande do Norte (UFRN) - Natal (RN), Brazil.

Doctorate in Oral Pathology from the Federal University of Rio Grande do Norte (UFRN) - Associate Professor II of the Department of Odontology of the Federal University of Rio Grande do Norte (UFRN) - Natal (RN), Brazil.

Post-doctoral award from the Barcelona Public Health Agency - Associate Professor I - Department of Odontology of the Federal University of Rio Grande do Norte (UFRN) - Natal (RN), Brazil. 


\section{INTRODUCTION}

The common mackerel skin or ephelides results from an increase in the synthesis of melanin pigment by basal layer melanocytes, with no increase in the number of melanocytes. Melanogenesis in skin can be attributed to actinic exposure. The ephelelides are seen more frequently in the face, nose, upper arms and trunk of genetically predisposed individuals, aged 6-18 and usually with red hair, fair skin and enhanced susceptibility to sunburn. Ephelides can also be found in the red edge of the lips, with the lower lip being the most prevalent site given that it tends to receive more sun exposure than the top lip. ${ }^{1}$

The lesion is macular, ranging from very small to over a centimeter in diameter. Ephelides occur equally in men and women and are asymptomatic. ${ }^{2}$ Freckles tend to be inherited as an autosomal dominant, and first-degree relatives are at greater risk of being carriers. ${ }^{3}$ Ephelides commonly occur in children and white-skinned young adults. Studies have demonstrated that ephelides prevalence varies according to different populations, ranging from 16 to $47.8 \%{ }^{4,5,6}$ Ephelides can be found to a greater of lesser extent in most, if not all, individuals. ${ }^{\top}$

Differential diagnoses for ephelides include solar lentigo, initial seborrheic keratosis, lentigo simplex, pigmented actinic keratosis and melanocytic nevus. The solar lentigo does not occur inside the mouth but is often observed on facial skin and is typically multiple, revealed as uniformly brown or yellowbrown stains with sharply demarcated but irregular borders. Size can be up to $1.0 \mathrm{~cm}$. Unlike what happens with freckles no change in intensity of staining is observed after exposure to UV light. ${ }^{1}$ The lentigo simplex is one of several forms of cutaneous melanocytic benign hyperplasia of unknown cause. It is darker than the ephelides and does not change with exposure to the sun. Some authors believe that lentigo simplex represents the earliest stage of another common skin lesion - melanonocytic nevus.

Nowadays solar radiation is the main lifestylerelated factor recognized as a major contributor to the development of skin cancer. ${ }^{8}$ While a substantial group of risk factors is known to cause the appearance of skin and lip lesions, and environmental and genetic factors contribute to skin cancer and other skin diseases, ultraviolet radiation is definitely known to be carcinogenic in humans.

Harmful UVB rays are more prevalent in tropical countries. Brazil has the highest levels of UV rays in the planet, with the state of Natal possessing one of the highest rates in all of Brazil 10, favoring the development of oral and perioral lesions, including skin cancer, actinic cheilitis and Epidermoid carcinoma. ${ }^{11,12}$
It is vital to be familiar with the aforementioned conditions which affect our population, particularly individuals constantly exposed to the sun (e.g. beach workers), so that appropriate preventive measures can be instituted. With this in mind, our study aimed to determine the prevalence of lip and perioral ephelides arising from sun exposure among people working on the 'urban' beaches of Natal (Rio Grande do Norte) and to investigate potential associations with sociodemographic, occupational and general health.

\section{METHODS}

It was hoped that this prevalence study would provide an understanding of the extent and severity of lip and perioral ephelides arising from sun exposure, and serve to verify how certain factors are linked to their appearance.

Workers at five urban beaches in Natal, capital of Rio Grande do Norte state, were allocated by convenience sampling on 28/29 August and 11/12 December 2010. The subjects agreed to participate in the study after reading a TCLE (term of informed consent) presented to them explaining the nature and structure of the work. After giving their consent, subjects were presented with a questionnaire containing sections on personal background, employment and health (the questionnaire was elaborated in three phases: a search of the academic literature, an evaluation by dentists, dermatologists and epidemiologists and, finally, 'cultural adaptation' of the questions to the universe studied. In addition, clinical extraoral examinations were undertaken in order to identify any specific damage existing that would be of interest to the study. The diagnoses were based on clinical aspects by previously calibrated examiners that considered the factors mentioned (Figure 1).

The sample consisted of individuals of both sexes exposed to sunlight, either directly or indirectly, and aged 18 and over. The sample design was based on the dissertation "Prevalence and factors associated with lip and perioral lesions resulting from sun exposure in beach workers". ${ }^{13}$ Given the non-existence of reliable estimates of the number of people actually working the city beaches, we conducted a pilot study of 120 randomly selected workers. In view of the prevalence noted in the pilot study of cold sores (36.6\%), and considering a margin of error of $15 \%$ and a nonresponse rate of $20 \%$, we estimated a total sample of 355 individuals.

The independent variables, all obtained through the questionnaire, were age, gender, income in Brazilian currency (the 'Real'), years of formal education, type of work (outdoor / indoor), occupational level, frequency of sun exposure on a weekly basis, 


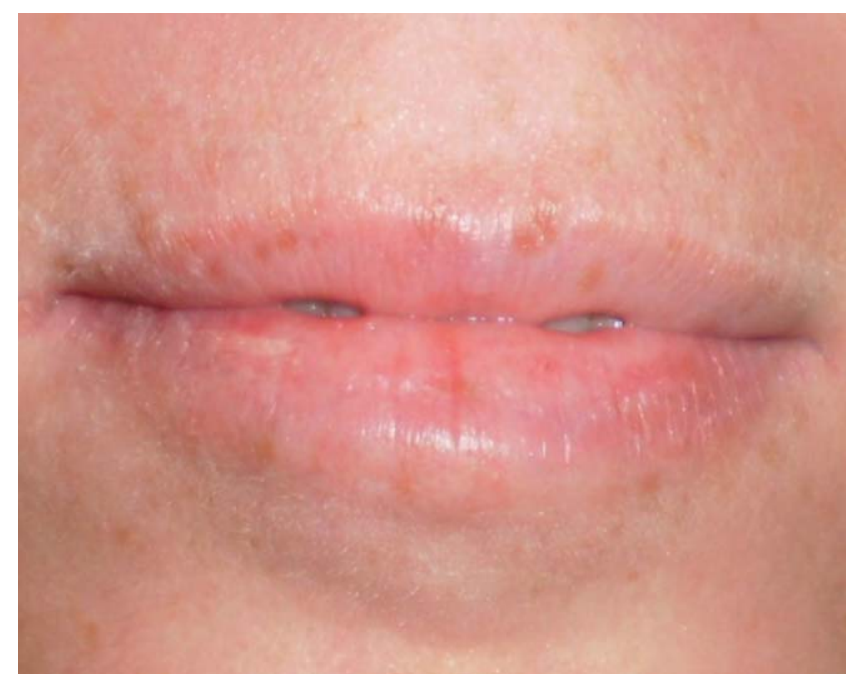

FIGURE 1: Clinical aspects of labial and perioral ephelides

length of daily sun exposure, cumulative hours of sun exposure, and protective measures taken (sunscreen, lip balm, cap / hat, lipstick, etc).

A number of other details were then collected from participants in the study: data on health status, habits (smoking and drinking - classified according to the number of cigarettes smoked in the last 30 days and standard measures of alcohol consumed

(one measure over the last 30 days or more than two standard measures per day). A standard measure corresponds to one can or half a bottle of beer, one glass of wine or a shot of liquor (according National Health Research criteria). ${ }^{14}$ We also asked people to record their skin types: according to Fitzpatrick, ${ }^{15}$ statistical analysis required the first three skin types to be considered 'fair' skin and the last three 'brown / dark' skin. The presence or absence of lip or perioral ephelides were the study's dependent variables.

The data were entered in the STATA 10.0 software platform. Analysis was conducted of descriptive data for all dependent and independent variables, chisquare statistical test, calculated prevalence ratios and confidence intervals. Quantitative variables were transformed into categorical variables from their medians. A significance level of $5 \%$ was considered for all the tests.

\section{RESULTS}

A workshop calibration was done by teaching staff of the Departments of Dentistry and Dermatology to minimize variations among different examiners. The result of the calibration process, measured by the kappa coefficient, ranged from 0.68 to 1.00 . Eight students from the dentistry and medicine courses were responsible for assembling the required information.
Results were obtained for 362 beach workers aged from 18-68. Males outnumbered females by 3 to 1 (three quarters of the sample) and formed the majority in all age groups, especially in the 18-26 and the $38-45$ brackets. The highest number of females were in the 27-37 age bracket.

At three data collection points the beach workers directly exposed to high radiation peaks caused by ultraviolet (outdoor) sunlight predominated.

As for socio-demographic variables, the study universe consisted predominently of individuals with six years schooling (with at least $50 \%$ of participants enrolled in educational establishments) and with an average monthly income of $\mathrm{R} \$ 510.00$. Average working time was 6 hours daily, 5 days a week over 8 years (9am to $4 \mathrm{pm}$ ). (Table 1).

Most of the workers reported using some means of protection from solar radiation, especially the use of caps or hats and sunscreen. Lip salve and certain other precautions were less in evidence. Around a quarter smoked cigarettes ( 1 to 10 per day), while the majority reported that they were teetotal (non-drinkers). Most of the beach workers were light or dark brown skinned. Individuals with very fair or black skin were a small minority. Around one third (33.7\%) were diagnosed with perioral ephelides and a quarter of them (24.0\%) with lip ephelides.

Socio-demographic data relating to workers diagnosed with labial and perioral lesions can be seen at Tables 2 and 3 respectively. Individuals with lip ephelides were generally under the median age of the sample. Those found with perioral lesions spent the same amount of cumulative time of exposure to sunlight, daily exposure (in hours) and weekly frequency of exposure very similar to the overall universe studied (Tables 1 and 2). As regards socio-economic variables, we observed that workers with lip lesions possessed higher schooling levels and incomes than the average. (Tables 1 and 3)

Combining the bivariate analysis model with sociodemographic, occupational and general health, only gender explained the presence of perioral ephelides $(p=0.002)$, with females presenting a 38\% higher prevalence of injuries compared to the males (Table 4). Regarding labial ephelides individuals with smoking or drinking habits were more likely to suffer lesions (RP 1.525) than those who did not indulge ( $p$ $=0.036)$. Drinkers were more predisposed to lesions than non-drinkers (RP 1.531) $(\mathrm{p}=0.030)($ Table 5).

\section{DISCUSSION}

Approximately one quarter of the workers had lip lesions and a third had perioral lesions. This was corroborated by individual historíes of 'occupational' sun exposure and possibly by the inappropriate (or 
TABLE 1: Description of the sample in accordance with socio-demographic and occupational variables. Natal, RN. 2010

\begin{tabular}{lllllll}
\hline $\begin{array}{l}\text { Variable } \\
\text { Sociodemographic }\end{array}$ & $\mathbf{n}$ & Median $\pm \mathbf{d p}$ & Median & $\mathbf{Q}$ 25-75 & Min & Max \\
\hline Age & 355 & $37.17 \pm 11.88$ & 37.00 & $27.00-45.00$ & 18.00 & 68.00 \\
Years of education & 355 & $6.49 \pm 3.98$ & 6.00 & $4.00-10.00$ & 0 & 17.00 \\
Income in Brazilian currency & 337 & $686.02 \pm 477.92$ & 510.00 & $400.00-800.00$ & 50.00 & 4200.00 \\
& & & & & & \\
Occupational & $\mathbf{n}$ & Median $\pm \mathbf{d p}$ & Median & $\mathbf{Q} 25-75$ & Min & Max \\
Job start time & 361 & $8.62 \pm 1.37$ & 9 & $8.00-10.00$ & 5.00 & 13.00 \\
Job finish time & 361 & $15.84 \pm 1.98$ & 16.00 & $14.00-17.00$ & 8.00 & 24.00 \\
Daily exposure in hours & 361 & $5.89 \pm 1.26$ & 6.00 & $7.00-6.00$ & 0 & 7.00 \\
Weekly exposure in days & 361 & $4.76 \pm 2.17$ & 5.00 & $2.50-7.00$ & 1.00 & 7.00 \\
Exposure in years & 361 & $10.07 \pm 9.66$ & 8.00 & $3.00-15.00$ & $1 / 12$ & 60.00 \\
Exposure in months & 361 & $121.27 \pm 115.60$ & 96.00 & $180.00-36.00$ & 1.00 & 720.00 \\
\hline
\end{tabular}

$\mathrm{n}=$ number of participants

$\mathrm{dp}=$ standard deviation

Q25-75 = interquartile distance

Min $=$ minimum

Max $=$ maximum

TABLE 2: Description of the population with perioral ephilides in accordance with sociodemographic and occupational variables. Natal, RN. 2010.

\begin{tabular}{|c|c|c|c|c|c|c|}
\hline \multirow{2}{*}{$\begin{array}{l}\text { Variable } \\
\text { Sociodemographic }\end{array}$} & \multicolumn{6}{|c|}{ Ephilides in perioral region } \\
\hline & $\mathbf{n}$ & Median $\pm d p$ & Median & Q 25-75 & Min & $\operatorname{Max}$ \\
\hline Age & 119 & $37.45 \pm 12.03$ & 37.00 & $27.00-45.00$ & 18.00 & 67.00 \\
\hline Years of education & 121 & $6.63 \pm 3.93$ & 6.00 & $4.00-11.00$ & 0 & 15.00 \\
\hline Income in Brazilian currency & 115 & $715.13 \pm 573.38$ & 500.00 & $350.00-1000.00$ & 50.00 & 4200.00 \\
\hline Occupational & $\mathbf{n}$ & Median \pm dp & Median & Q 25-75 & Min & $\operatorname{Max}$ \\
\hline Job start time & 122 & $8.57 \pm 1.55$ & 9 & $7.00-10.00$ & 5.00 & 13.00 \\
\hline Job finish time & 122 & $16.07 \pm 2.22$ & 16.00 & $15.00-17.00$ & 10.00 & 24.00 \\
\hline Daily exposure in hours & 122 & $5.86 \pm 1.30$ & 6.00 & $5.00-7.00$ & 1.00 & 7.00 \\
\hline Weekly exposure in days & 121 & $4.49 \pm 2.25$ & 5.00 & $2.00-7.00$ & 1.00 & 7.00 \\
\hline Exposure in years & 122 & $11.11 \pm 11.27$ & 8.00 & $3.00-17.00$ & $1 / 12$ & 60.00 \\
\hline Exposure in months & 122 & $133.50 \pm 135.22$ & 96.00 & $36.00-204.00$ & 1.00 & 720.00 \\
\hline
\end{tabular}

$\mathrm{n}=$ number of participants

$\mathrm{dp}=$ standard deviation

Q25-75 = interquartile distance

Min $=$ minimum

$\operatorname{Max}=$ maximum

TABLE 3: Description of the population with labial ephilides in accordance with sociodemographic and occupational variables. Natal, RN. 2010.

\begin{tabular}{|c|c|c|c|c|c|c|}
\hline \multicolumn{2}{|l|}{ Variable } & \multicolumn{5}{|c|}{ Ephelides in labial region } \\
\hline Sociodemographic & $\mathbf{n}$ & Median $\pm d p$ & Median & Q 25-75 & Min & $\operatorname{Max}$ \\
\hline Age & 87 & $36.74 \pm 11.45$ & 36.00 & $27.00-44.00$ & 18.00 & 63.00 \\
\hline Years of education & 86 & $6.77 \pm 4.07$ & 7.50 & $3.00-11.00$ & 0 & 14.00 \\
\hline Income in Brazilian currency & 80 & $681.88 \pm 424.12$ & 525.00 & $412.50-875.00$ & 50.00 & 2000.00 \\
\hline Occupational & $\mathbf{n}$ & Median \pm dp & Median & Q 25-75 & Min & $\operatorname{Max}$ \\
\hline Job start time & 87 & $8.33 \pm 1.40$ & 8.00 & $7.00-9.00$ & 5.00 & 12.00 \\
\hline Job finish time & 87 & $15.68 \pm 2.41$ & 16.00 & $14.00-17.00$ & 8.00 & 24.00 \\
\hline Daily exposure in hours & 87 & $5.72 \pm 1.45$ & 6.00 & $5.00-7.00$ & 0 & 7.00 \\
\hline Weekly exposure in days & 87 & $4.83 \pm 2.34$ & 6.00 & $2.00-7.00$ & 1.00 & 7.00 \\
\hline Exposure in years & 87 & $9.54 \pm 9.65$ & 7.00 & $3.00-13.00$ & $1 / 12$ & 53.00 \\
\hline Exposure in months & 87 & $114.63 \pm 115.66$ & 84.00 & $36.00-156.00$ & 1.00 & 636.00 \\
\hline
\end{tabular}


TABLE 4: Frequencies. Qui test 2. p value. RPs and respective confidence intervals of the results showing presence of perioral ephelides associated to variables of a sociodemographic. occupational and general health nature. Natal, RN. 2010.

\begin{tabular}{|c|c|c|c|c|c|c|}
\hline \multirow{2}{*}{$\frac{\text { Variable }}{\text { Gender }}$} & \multirow[b]{2}{*}{$\mathbf{n}$} & \multicolumn{3}{|c|}{ Presence of perioral ephelides } & \multirow[b]{2}{*}{ RPnaj } & \multirow[b]{2}{*}{ IC (95\%) } \\
\hline & & $\%$ & Qui 2 & p value & & \\
\hline Male & 76 & 28.9 & 9.164 & 0.002 & 0.622 & $0.468-0.826$ \\
\hline Female & 46 & 46.5 & & & & \\
\hline Age & $\mathbf{n}$ & $\%$ & Qui 2 & p value & RPnaj & IC (95\%) \\
\hline 37 years and over & 57 & 33.5 & 0.001 & 1.000 & 1.000 & $0.746-1.341$ \\
\hline Up to 37 years & 62 & 33.5 & & & & \\
\hline Years of education & $\mathbf{n}$ & $\%$ & Oui 2 & p value & RPnaj & IC (95\%) \\
\hline Up to 6 years & 64 & 33.7 & 0.003 & 0.953 & 0.975 & $0.730-1.303$ \\
\hline 6 years and over & 57 & 34.5 & & & & \\
\hline Income in Brazilian currency (reais) & $\mathbf{n}$ & $\%$ & Qui 2 & p value & RPnaj & IC (95\%) \\
\hline Up to 510.00 & 64 & 37.2 & 1.220 & 0.269 & 1.204 & $0.892-1.624$ \\
\hline 510.00 and over & 51 & 30.9 & & & & \\
\hline Type of employment & $\mathbf{n}$ & $\%$ & Qui 2 & p value & RPnaj & IC (95\%) \\
\hline Outdoor & 104 & 32.7 & 0.826 & 0.363 & 0.799 & $0.542-1.179$ \\
\hline Indoor & 18 & 40.9 & & & & \\
\hline Daily exposure & $\mathbf{n}$ & $\%$ & Qui 2 & p value & RPnaj & IC (95\%) \\
\hline 6 hours and over & 53 & 34.4 & 0.011 & 0.918 & 1.032 & $0.772-1.381$ \\
\hline Up to 6 hours & 69 & 33.3 & & & & \\
\hline Weekly exposure & $\mathbf{n}$ & $\%$ & Qui 2 & p value & RPnaj & IC (95\%) \\
\hline 5 days and over & 54 & 30.2 & 1.503 & 0.220 & 0.819 & $0.611-1.099$ \\
\hline Up to 5 days & 67 & 36.8 & & & & \\
\hline Cumulative exposure & $\mathbf{n}$ & $\%$ & Qui 2 & p value & RPnaj & IC (95\%) \\
\hline 8 years or over & 55 & 34.0 & 0.001 & 1.000 & 1.008 & $0.754-1.348$ \\
\hline Up to 8 years & 67 & 33.7 & & & & \\
\hline Photo protection & $\mathbf{n}$ & $\%$ & Qui 2 & p value & RPnaj & IC (95\%) \\
\hline No & 20 & 27.8 & 1.100 & 0.294 & 0.790 & $0.527-1.183$ \\
\hline Yes & 102 & 35.2 & & & & \\
\hline Use of sunscreen & $\mathbf{n}$ & $\%$ & Qui 2 & p value & RPnaj & IC (95\%) \\
\hline No & 66 & 31.3 & 1.178 & 0.278 & 0.838 & $0.628-1.118$ \\
\hline Yes & 56 & 37.3 & & & & \\
\hline Use of cap or hat & $\mathbf{n}$ & $\%$ & Qui 2 & $p$ value & RPnaj & IC (95\%) \\
\hline No & 37 & 30.3 & 0.770 & 0.380 & 0.853 & $0.620-1.173$ \\
\hline Yes & 85 & 35.6 & & & & \\
\hline Skin type & $\mathbf{n}$ & $\%$ & Qui 2 & $p$ value & RPnaj & IC (95\%) \\
\hline Fair & 43 & 37.4 & 0.755 & 0.385 & 1.165 & $0.864-1.571$ \\
\hline Black/brown & 78 & 32.1 & & & & \\
\hline Habits & $\mathbf{n}$ & $\%$ & Qui 2 & $p$ value & RPnaj & IC (95\%) \\
\hline Yes & 64 & 35.0 & 0.165 & 0.685 & 1.079 & $0.808-1.442$ \\
\hline No & 58 & 32.4 & & & & \\
\hline Drinking & $\mathbf{n}$ & $\%$ & Qui 2 & $p$ value & RPnaj & IC (95\%) \\
\hline Yes & 49 & 33.8 & 0.001 & 1.000 & 1.005 & $0.748-1.349$ \\
\hline No & 73 & 33.6 & & & & \\
\hline Smoking & $\mathbf{n}$ & $\%$ & Qui 2 & $p$ value & RPnaj & IC (95\%) \\
\hline Yes & 31 & 34.4 & 0.002 & 0.965 & 1.030 & $0.740-1.433$ \\
\hline No & 91 & 33.5 & & & & \\
\hline
\end{tabular}


TABLE 5: Frequencies. Qui test 2. p value. RPs and respective confidence intervals of the results showing presence of labial ephelides associated to variables of a sociodemographic, occupational and general health nature. Natal, RN. 2010

\begin{tabular}{|c|c|c|c|c|c|c|}
\hline \multirow{2}{*}{$\frac{\text { Variable }}{\text { Gender }}$} & \multicolumn{6}{|c|}{ Presence of labial ephelides } \\
\hline & $\mathbf{n}$ & $\%$ & Qui2 & p value & RPnaj & IC (95\%) \\
\hline Male & 66 & 25.1 & 0.400 & 0.527 & 1.183 & $0.767-1.825$ \\
\hline Female & 21 & 21.2 & & & & \\
\hline Age & $\mathbf{n}$ & $\%$ & Qui2 & $p$ value & RPnaj & IC (95\%) \\
\hline 37 years and over & 38 & 22.4 & 0.610 & 0.435 & 0.844 & $0.584-1.221$ \\
\hline Up to 37 years & 49 & 26.5 & & & & \\
\hline Years of education & $\mathbf{n}$ & $\%$ & Qui2 & p value & RPnaj & IC (95\%) \\
\hline Up to 6 years & 42 & 22.1 & 0.768 & 0.381 & 0.829 & $0.574-1.197$ \\
\hline 6 years and over & 44 & 26.7 & & & & \\
\hline Income in Brazilian currency (reais) & $\mathbf{n}$ & $\%$ & Qui2 & $p$ value & RPnaj & IC (95\%) \\
\hline Up to 510.00 & 40 & 23.3 & 0.007 & 0.932 & 0.959 & $0.654-1.407$ \\
\hline 510.00 and over & 40 & 24.2 & & & & \\
\hline Type of employment & $\mathbf{n}$ & $\%$ & Qui2 & $p$ value & RPnaj & IC (95\%) \\
\hline Outdoor & 75 & 23.6 & 0.121 & 0.728 & 0.865 & $0.513-1.457$ \\
\hline Indoor & 12 & 27.3 & & & & \\
\hline Daily exposure & $\mathbf{n}$ & $\%$ & Qui2 & $p$ value & RPnaj & IC (95\%) \\
\hline 6 hours and over & 38 & 24.7 & 0.009 & 0.923 & 1.042 & $0.721-1.507$ \\
\hline Up to 6 hours & 49 & 23.7 & & & & \\
\hline Weekly exposure & $\mathbf{n}$ & $\%$ & Qui2 & $p$ value & RPnaj & IC (95\%) \\
\hline 5 days and over & 46 & 25.7 & 0.338 & 0.561 & 1.141 & $0.790-1.646$ \\
\hline Up to 5 days & 41 & 22.5 & & & & \\
\hline Cumulative exposure & $\mathbf{n}$ & $\%$ & Qui2 & $p$ value & RPnaj & IC (95\%) \\
\hline 8 years or over & 34 & 21.0 & 1.263 & 0.261 & 0.788 & $0.540-1.149$ \\
\hline Up to 8 years & 53 & 26.6 & & & & \\
\hline Photo protection & $\mathrm{n}$ & $\%$ & Qui2 & $\mathrm{p}$ value & RPnaj & IC (95\%) \\
\hline No & 19 & 26.4 & 0.136 & 0.712 & 1.125 & $0.726-1.744$ \\
\hline Yes & 68 & 23.4 & & & & \\
\hline Use of sunscreen & $\mathbf{n}$ & $\%$ & Qui2 & $p$ value & RPnaj & IC (95\%) \\
\hline No & 53 & 25.1 & 0.314 & 0.575 & 1.142 & $0.780-1.671$ \\
\hline Yes & 33 & 22.0 & & & & \\
\hline Use of cap or hat & $\mathbf{n}$ & $\%$ & Qui2 & $p$ value & RPnaj & IC (95\%) \\
\hline No & 27 & 22.1 & 0.167 & 0.683 & 0.896 & $0.601-1.337$ \\
\hline Yes & 59 & 24.7 & & & & \\
\hline Skin type & $\mathbf{n}$ & $\%$ & Qui2 & $p$ value & RPnaj & IC (95\%) \\
\hline Fair & 25 & 21.7 & 0.317 & 0.573 & 0.866 & $0.575-1.304$ \\
\hline Black/brown & 61 & 25.1 & & & & \\
\hline Habits & $\mathbf{n}$ & $\%$ & Qui2 & $p$ value & RPnaj & IC (95\%) \\
\hline Yes & 53 & 29.0 & 4.393 & 0.036 & 1.525 & $1.045-2.226$ \\
\hline No & 34 & 19.0 & & & & \\
\hline Drinking & $\mathbf{n}$ & $\%$ & Qui2 & p value & RPnaj & IC (95\%) \\
\hline Yes & 44 & 30.3 & 4.717 & 0.030 & 1.531 & $1.064-2.204$ \\
\hline No & 43 & 19.8 & & & & \\
\hline Yes & 24 & 26.7 & 0.283 & 0.595 & 1.151 & $0.768-1.727$ \\
\hline No & 63 & 23.2 & & & & \\
\hline
\end{tabular}


none) use of protective measures. The National Campaign to Prevent Skin Cancer run by the Brazilian Society of Dermatology in 2009 diagnosed 1078 skin lesions in people living in Natal. ${ }^{16}$ Among the lesions identified were Basal Cell Carcinoma (135), squamous cell carcinoma (24) and potentially malignant lesions (213). The Nacional Cancer Institute (NIC) estimated that for year 2010, around 3000 new skin cancers, affecting different parts of the body, were found, ${ }^{17}$ making Rio Grande do Norte one of the Brazilian states with the highest incidence of skin cancer.

The occupational variables referring to photoprotection measures revealed that most of the beach workers who took precautionary measures against ultraviolet radiation (e.g. sunscreen) were affected by the same proportion of lesions as those who took no measures. It was clear that the way in which protective measures were employed was a factor in understanding why lesions emerged. In other words poor or non-existent quality of protection could explain the high prevalence of diagnosed lesions.

Only the gender variable was significantly associated $(\mathrm{p}=0.002)$ with the occurrence of perioral ephelides - females predominated (46.5\%). Males were (and are) more likely to occupy more sun-exposed jobs due to their greater physical strength. ${ }^{18,19,20,21}$ It is hardly surprising therefore that they develop more skin and lip lesions compared to females, although our findings contradicted this. This can probably be explained by local cultural customs and the types of solar protection generally used. Female workers reported, for example, taking significantly fewer measures than their male counterparts. Group composition also plays a significant role: females tend to predominate in aquatic and recreational jobs whereas males tend to gravitate towards employment in agriculture, general services, construction, transport and the ski industry. ${ }^{22}$

The occurrence of lip ephelides variables were significantly associated to insalubrious habits $(\mathrm{p}=$ 0.036) and alcoholism (0.030). Individuals who had a habit were generally in worse health than those who did not (29\%). Drinkers had more lesions than nondrinkers (30.3). The relationship between indulging a habit and lesions is not well addressed in the literature. However, we suggest that people who consume alcohol or smoke are less concerned about maintaining healthy habits. The fact is that beach workers with habits were more exposed to sunlight and reported less use of protective measures.

Alcohol is one of the few psychotropic drugs permitted and encouraged by society. According to the World Health Organization (WHO), mortality and limited functional status associated with the consumption of alcoholic beverages exceed those associated with tobacco. ${ }^{23}$ In recent decades alcohol consumption has been on the increase worldwide, mainly in developing countries. The literature shows that alcohol abuse is more frequent among males. Brazilian demographic studies reveal that alcoholism is associated closely with socioeconomic status, education, occupation and income. ${ }^{24,25,26}$

This study aimed to contribute to a deeper understanding by health professionals of the epidemiological aspects of Ephelides and to draw attention to the harmful effects of UV radiation on health, especially of workers intensely exposed to the sun by reason of their jobs. It is important to adopt educational and preventive measures for this population.

\section{CONCLUSION}

Our study revealed that the prevalence of lip and perioral ephelides in beach workers is high. The variables gender and alcohol consumption were significantly associated with the occurrence of skin diseases. Although most workers in this category reported the use of sunscreens, we observed that individuals failed to use UV protection measures appropriately. A need exists for social policies targetted at encouraging the use of prevention measures and for further studies to address the problems involved, with the overall aim of improving the health and working conditions of this particular population. 


\section{REFERENCES}

1. Neville BW, Damm DD, Allen CM, Bouquot JE. Patologia oral \& maxillofacial. 3. ed. Rio de Janeiro: Elsevier; 2009.972p

2. Cancer.org [Internet]. American Cancer Society. Cancer facts and figures 2006 Atlanta: American Cancer Society. [cited 2008 oct1]. Available from: http:www.cancer.org/docroot/home/index.asp

3. Yang S, Xu SX, Xiao FL, Du WH, Hao JH, Wang HY,et al. Prevalence and familial risk of ephelides in Han Chinese adolescents. Arch Dermatol Res. 2008; 300:87-90.

4. Bakos L, Wagner M, Bakos RM, Leite CS, Sperhacke CL, Dzekaniak KS,et al. Sunburn, sunscreens, and phenotypes: some risk factors for cutaneous melanoma in southern Brazil. Int J Dermatol. 2002;41:557-62.

5. Bastiaens MT, Westendorp RG, Vermeer BJ, Kavinck JN. Ephelides are more related to pigmentary constitutional host factors than solar lentigines. Pigment Cell Res. 1999;12:316-22.

6. Schäfer T, Merkl J, Klemm E, Wichmann HE, Ring J; KORA Study Group. The epidemiology of nevi and signs of skin aging in the adult general population: Results of the KORA-survey. J Invest Dermatol. 2006;126:1490-6.

7. Sampaio SAP, Riviti EA. Dermatologia. 3, ed. São Paulo: Artes Médicas; 2007.

8. SBD.org [Internet]. Sociedade Brasileira de Dermatologia. Doenças de Pele. [accessed on 18 Nov 2010]. Available at hhtp: www.sbd.org.br.

9. International Agency for Research on Cancer. Solar and ultraviolet radiation (IARC) Monographs on the evaluation of carcinogenic risks to humans. Lyon: IARC; 1992 316 p. (Solar and ultraviolet radiation; vol 55).

10. KirchhoffVWJH. Ozônio e Radiação UVB. São Paulo: Transtec Editorial; 1995.

11. Ramirez CC, Federman DG, Kirsner RS. Skin cancer as an occupational disease: the effect of ultraviolet and other forms of radiation. Int J Dermatol. 2005;44:95-100.

12. Silva FD, Daniel FI, Grando LJ, Calvo MC, Rath IBS, Fabro SML. Estudo da prevalência de alteraçôes labiais em pescadores na Ilha de Santa Catarina. Revista Odonto Ciencia. 2006;21:37-42.

13. Lucena EES. Prevalência e fatores associados a lesões labiais e periorais em trabaIhadores de praia [dissertação].Natal (RN): Universidade Federal do Rio Grande do Norte; 2011. $101 \mathrm{p}$

14. Brasil. Ministério da Saúde. Secretaria de Vigilância em Saúde. Instituto Nacional do Câncer. Inquérito Domiciliar sobre Comportamentos de Risco e Morbidade Referida de Doenças e Agravos não Transmissíveis. Brasil, 15 capitais e Distrito Federal 20022003. Rio de Janeiro: INCA, 2004. 186 p.

15. Fitzpatrick TB. The validity and practicality of sunreactive skin types. I -VI. Arch Dermatol. 1988;124:869-71.

16. SBD.tempsite [ Internet].Sociedade Brasileira de Dermatologia. Campanha Nacional de Prevenção contra o Câncer de Pele. [accessed on 2 Feb 2011]. Available at: http://sbd.tempsite.ws/capele/gestao/relatorios.asp?campanha $=1$.

17. Brasil. Ministério da Saúde. Instituto Nacional do Câncer. Estimativas da Incidência e Mortalidade por Câncer no Brasil para 2010. Rio de Janeiro: INCA; 2009. 98 p.
18. Araki K, Nagano T, Ueda M, Washio F, Watanabe S, Yamaguchi N,et al. Incidence of skin cancers and precancerous lesions in Japanese-risk factors and prevention. Epidemiol. 1999;9(6 Suppl):S14-21.

19. Frost CA, Green AC, Williams GM. The prevalence and determinants of solar keratoses at a subtropical latitude Queensland, Australia. Br J Dermatol. 1998;139: 1033-9.

20. Kennedy C, Bajdik CD, Willemze R, De Gruiil FR, Bouwes Bavinck JN; Leiden Skin Cancer Study. The influence of painful sunburns and lifetime sun exposure in the risk of actinic keratoses, seborrheic warts, melanocytic nevi, atypical nevi, and skin cancer. J Invest Dermatol. 2003;120:1087-93

21. Memon AA, Tomenson JÁ, Bothwell J, Friedmann PS. Prevalence of solar damage and actinic keratosis in a Merseyside population. Br J Dermatol. 2000;142:1154-9.

22. Steffen $A D$, Glanz K, Wilkens LR. Identifying latent classes of adults at risk Risk for Skin Cancer Based on Constitutional Risk and Sun Protection Behavior. Cancer Epidemiol Biomarkers Prev. 2007;16:1422-7.

23. Who.int [Internet]. World Health Organization. About global alcohol database. Geneva: WHO; 2002. [cited 2011 mar 13]. Available from: http://www3.who.int/whosis/alcohol/alcohol_about_us.cfm?path=whosis,alcohol,alcohol_about\&language =e nglish>.

24. Almeida LM, Coutiho E SF. Prevalência de consumo de bebidas alcoólicas e de alcoolismo em uma região Metropolitana do Brasil. Rev Saúde Pública. 1993;27: 23-9.

25. Almeida-Filho N, Lessa I, Margalhães L, Araujo MJ, Kawachi I. Determinantes sociais e padrões de consumo de álcool na Bahia, Brasil. Rev Saúde Pública. 2004:38:45-54.

26. Costa JSD, Silveira MF, Gazalle FK, Oliveira SS, Hallal PC, Menezes AM. Heavy alcohol consumption and associated factors: a population-based study. Rev Saúde Pública. 2004;38:284-91.

MAILING ADDRESS:
Eudes Euler de Souza Lucena
Av. Senador Salgado Filho, 1787
Lagoa Nova
59078970 Natal, RN.
Brazil
E-mail: eudeseuler@hotmail.com

How to cite this article: Lucena EES,CastroACQ, Farias DB, Lima PT, Silveira EJD, Lima KC. Prevalence of lip and perioral Ephelides in beach workers. An Bras Dermatol. 2013;88(1):56-63. 